C2017, Elsevier. Licensed under the Creative Commons Attribution-NonCommercialNoDerivatives 4.0 International http://creativecommons.org/about/downloads

(9) $\odot \Theta \Theta$ 


\title{
Local formal interpersonal networks and SMEs internationalisation: Empirical evidence from the UK
}

\begin{abstract}
This article uses data from the UK Longitudinal Small Business Survey (2015) to empirically test the relationship between local (formal and informal) interpersonal networks and exporting. Our results suggest that local interpersonal networks increase the likelihood of exporting. More importantly, we find that the role of formal interpersonal networks (e.g. accountants) on internationalisation increases as firm size increases, while the link between informal interpersonal networks (e.g. family) and exporting becomes weaker. We argue that larger firms have more complex operations and diverse structures than smaller firms that require the engagement of formal interpersonal networks to help with the internationalisation process.
\end{abstract}

Keywords: interpersonal networks, formal networks, informal networks, SMEs, internationalisation, exporting 


\section{Introduction}

Research regarding the role of networks in the internationalisation process of small and medium-sized firms (SMEs) has been gaining significant attention during the past few years (Zhang, Ma \& Wang, 2012; Boehe, 2013; Hånell \& Ghauri, 2016; Stoian, Rialp, Rialp \& Jarvis, 2016; Rosenbaum, 2017). However, previous studies dealt with the network concept as 'something uni-dimensional' (Eberhard \& Craig, 2013, p. 386). Hence, there is a growing call in the literature that research should move beyond 'one-size-fits-all analyses of networks' (e.g. Inkpen \& Tsang, 2005, p. 161). Previous literature calls for more evidence on the specific types of networks, specifically the role of interpersonal networks ${ }^{1}$, and their effect on firms' internationalisation (Ellis \& Pecotich, 2001; Zhou, Wu \& Luo, 2007; Eberhard \& Craig, 2013), and this paper responds to this call.

A small, but growing literature on interpersonal networks reveals that entrepreneurs' international expansions and exporting decisions can be influenced by their interpersonal network relationships with others (Zhou et al., 2007; Narooz \& Child, 2016; Zaefarian, Eng \& Tasavori, 2016). Additionally, previous research emphasises the role of foreign networks and foreign relationships in assisting firms to internationalise (Ellis \& Pecotich, 2001; Manolova, Manev \& Gyoshev, 2010). Importantly, although a few studies stress the importance of the role of local networks in gaining access to international markets (e.g. Boehe, 2013), the empirical evidence remains scarce (Milanov \& Fernhaber, 2014; Prashantham \& Birkinshaw, 2015; Haddoud, Jones \& Newbery, 2017). This is surprising since early research suggests that internationalisation is strongly associated with networks in the domestic market in which the firm operates (e.g. Johanson \& Mattsson, 1988; Ellis, 2000). Porter (1998, p. 5), for example, argues that firms' competitive advantages often arise from local contacts such as 'institutions, rivals, and sophisticated customers in a particular region'.

In this paper, we focus on interpersonal networks at the individual level rather than inter-firm networks since opportunities are being exploited by individuals and not by firms (Singh, 2000; Shane, 2003). Building on and expanding previous literature (e.g. Holmlund \& Kock, 1998; Zhang, Ma, Wang, Li \& Huo, 2016), our interest is concentrated on interpersonal networks of SMEs and their role on firms' exporting, which serves as a proxy for internationalisation. In particular, we differentiate between local interpersonal networks (such as accountants, banks, solicitors and consultants) generated in the local (domestic)

\footnotetext{
${ }^{1}$ Interpersonal networks can be defined as networks that consist of all individuals with whom owner-managers have direct relationships and obtain advice, information and support from (Eberhard \& Craig, 2013).
} 
market in which the firm operates (in this case, the UK) and non-local networks (such as customers and suppliers) located in the international (foreign) market the firm intends to enter (i.e. outside the UK). To do this, we build on the work framed within the network perspective (Johanson \& Mattsson, 1988) and social network theory (e.g. Mitchell, 1969), which enables us to add to existing literature, and specifically to the social network theory of internationalisation, however, we add to existing literature by distinguishing between formal and informal interpersonal networks (see Fernhaber \& $\mathrm{Li}, 2012$ ). We argue that this distinction is important since learning from networks generally depends on the formal versus the informal mechanism within the network (Almeida, Dokko \& Rosenkopf, 2003). Formal networks can be defined as a 'formally specified set of relationships', while informal networks consist of more flexible relationships where the purpose of the interaction may not be related to work only, but could be social as well (Ibarra, 1993, p. 58).

The paper mainly draws on the Social Network Theory (SNT) of internationalisation and previous work in the field (Kingsley \& Malecki, 2004; Coviello, 2006; Mort \& Weerawardena, 2006; Zhang et al., 2016) and empirically examines the effect of both formal and informal local interpersonal networks on different-sized SMEs using data from the first wave of the UK Longitudinal Small Business Survey (UKLSBS) of 2015. This allows us to observe differences between larger-sized SMEs and smaller ones, which can be hidden when data is aggregated. Hence, this paper makes a substantial contribution to the IE (e.g. Ellis, 2001; Frenhaber \& Li, 2012; Zhang et al., 2016), IB (e.g. Chetty \& Blankenburg-Holm, 2000; Boehe, 2013; Eberhard \& Craig, 2013) and small business literature (e.g. Larsson, Hedelin \& Garling, 2003; Hånell \& Ghauri, 2016) by providing for the first time empirical evidence on the association between interpersonal networks and exporting propensity within different-sized SMEs. Notably, our paper not only directly responds to the academic call for more research in this area (e.g. Ellis \& Pecotich, 2001; Zhou et al., 2007), but also provides new policy avenues to help SMEs enter new markets and boost exporting activity through their networking strategy. Overall, the findings strongly suggest that local interpersonal networks increase the likelihood of SMEs exporting. In particular, as firm size increases, the role of formal interpersonal networks (e.g. accountants, banks) on firms' exporting becomes stronger. Additionally, our results show that micro firms are reluctant to network with outside sources. We therefore argue that analysing SMEs as one group of firms cannot unfold particular differences that lie within different size bands.

The paper is organised as follows. Section 2 discusses the existing literature on the relationship between interpersonal networks and SME internationalisation, and offers the 
derivation of the hypotheses to be tested. Section 3 discusses the data. Section 4 presents the model and discusses the results. The final section concludes the paper and provides directions for future research.

\section{Background and derivation of hypotheses}

\subsection{Defining networks and the benefits of networking}

Although most studies fail to provide an exact definition of networks (see review by Hohenthal, Johanson \& Johanson, 2014), there are three commonly used approaches to define networks. The first approach views a network as a 'system of interrelated actors' (Hohenthal et al., 2014, p. 10) such as customers, suppliers, competitors, family members and friends (Zain \& Ng, 2006; Evers \& Knight, 2008). The second approach comes from the purpose of the relationship, such as business or social relationships (Evers \& O'Gorman, 2011). The third approach is based on the structure of the network, suggesting that a network is a set of two or more connected relationships (Axelsson \& Easton, 1992; Coviello \& Munro, 1997; Chetty \& Blankenburg-Holm, 2000).

Advice networks, for example, involve relationships where individuals share resources and obtain support and information (Sparrowe, Liden, Wayne \& Karimer, 2001). Hoang and Antoncic (2003) suggest that pursuing advice/information is considered the main reason for networking. As discussed in Hoang and Antoncic (2003), most of the existing research on SMEs considers network relationships from this perspective, which is based on strong exchange of information and trust. In this paper, we follow their argument, which implies that seeking external advice/information is the primary reason for networking.

The SNT implies that in order for businesses to flourish, owner-managers should have the ability to gain access to resources that are controlled by other firms or individuals. Resources that exist externally can be obtained through networking (Jarillo, 1989; Florin, Lubatkin \& Schulze, 2003). A study conducted by Donckels and Lambrecht (1995) shows that the growth of a firm is positively associated with developing and maintaining network relationships either nationally or internationally, while Larsson, Hedelin and Garling (2003) demonstrate that the lack of network relationships with outside advisors and experts is an obstacle for small businesses to expand and grow their firms further. Therefore, entrepreneurs' reliance on networks is not limited to the start-up stage. Network relationships provide entrepreneurs with business information and advice, and offer help to solve problems (Johannisson, Alexanderson, Nowicki \& Senneseth, 1994). 
Based on the empirical evidence, which favours the positive effect of networking, it is appropriate to expect that firms who succeed and survive are more likely to be more active in networks than other firms. However, Watson (2007) implies that the relationship between the level of networking undertaken by SMEs owner-managers and a firm's performance is an inverted U-shaped relationship. Although it is reasonable to assume that some level of networking is useful, it is also reasonable to propose, according to the law of diminishing returns, that a high level of networking is more likely to generate negative effects. Based on economists' argument that time is a scarce economic resource, and on the way individuals allocate their time (Uzzi, 1997), it may be unlikely that SMEs owners will have the time to network and run a sustainable business simultaneously. Therefore, the relationship between networking and small firms' performance will take the form of an inverted U-shape rather than being a linear relationship. It can be argued, however, that networks have positive effects on the success and expansion of SMEs and firms in general. Coleman (1988) demonstrates that information is important for owners to make strategic decisions. Hence, networking can develop owners' social capital because access to knowledge and information needed for firms' growth can be obtained through these relationships.

\subsection{Networks and internationalisation}

SNT is considered one of the dominant theories that explain firms' internationalisation. Previous studies combined different theories with the network approach to examine the internationalisation process of firms. Two of the most widely applied models are the Uppsala Internationalisation Model and the Born Global Model. From an internationalisation perspective, Johanson and Vahlne (1992) find that network relationships influence firms to enter foreign markets in a gradual process. Firms are successful in expanding their businesses abroad because of their position in a network within their current markets (Johanson \& Mattsson, 1988). However, in recent years more researchers have started paying attention to a special type of small firm, the born global firm. This type of firm has the ability to enter global markets rapidly from their inception. The Born-Global model has challenged incremental or gradual internationalisation theories by indicating that small firms can overcome their resource constraints through their network relationships (Mort \& Weerawardena, 2006). Therefore, researchers adopting the Born-Global model have emphasised the role of networking in contributing to the success of these types of firms. Previous literature shows that network relationships help born global firms to acquire the required market knowledge and identify market opportunities (Coviello \& Munro, 1995). 
From a network perspective, internationalisation refers to the development and establishment of relationships in foreign networks. The foundation of this perspective is that a firm is dependent on resources that are controlled by other firms. Through participating in networks, access to resources can be obtained either by developing existing ties or by establishing new ones. Hence, it has been suggested that participation in a network relationship gives firms the benefits of insidership (Ghauri, Tasavori \& Zaefarian, 2014). This applies to small firms since they face greater entry barriers than larger firms, so it is more difficult for them to obtain trust from prospective network partners (Zahra, 2005). Networks may assist firms in gaining access to a wide range of resources such as "political influence, reputation and mutual trust' (Boehe, 2013, p. 168). The emphasis is on the gradual learning and the attainment of knowledge through interactions. Through this process, firms will internationalise by developing ongoing relationships and increase their resource commitments among networks (Johanson \& Mattsson, 1988).

Sharma and Johanson (1987) suggest that when firms operate in a network consisting of relationships, these relationships will develop further to become channels to international markets. However, due to the criticisms of the Stage model and the Born-Global model, the SNT of internationalisation has emerged, which focuses more on individual-level relationships rather than on firm-level relationships. For instance, Ellis's (2000) study shows that interpersonal relationships and connections provide firms with foreign opportunities, while Zhou et al. (2007) suggest that social networks produce information and facilitate the relationship between internationalisation and firms' performance. Social networks are important for SMEs because firms can exchange information, which will lead them to duplicate each other and speed up the exporting process (Bonaccorsi, 1992; Robert \& Antoncic, 2006; Ge \& Wang, 2013). Moreover, being part of a network allows ownermanagers to 'exchange and combine their resources through various activities for their mutual benefits' (Ghauri et al., 2014, p. 580). Social networks also offer advice and information (Hoang \& Antoncic, 2003), which are crucial for firms' development. Ownermanagers seek advice in order to obtain opinions and judgements regarding current strategies and alternative opportunities (McDonald \& Westphal, 2003). Advice and information from external sources are usually sought from individuals who lack the appropriate knowledge to make decisions related to their firms (Menon \& Pfeffer, 2003). ${ }^{2}$ Therefore, networks enable

\footnotetext{
${ }^{2}$ In addition, the resource-based view theory of the firm (RBV) highlights the advantages of seeking external advice and information. Small and young firms can overcome their limited resources and skills by obtaining
} 
owner-managers to gain access to different kinds of resources (Boehe, 2013) where ownermanagers will have the ability to learn and gain knowledge in a gradual way. Through this process, firms can internationalise by developing ongoing relationships and increase their resource commitments among their network relationships (Johanson \& Mattsson, 1988).

Previous literature emphasises the role of networks in the internationalisation process of SMEs. For instance, Bonaccorsi (1992) argues that small firms use network relationships in order to obtain information, knowledge and trade, which in turn enhance their exporting activities. In addition, Zain and $\mathrm{Ng}$ (2006) find that small software companies use their network relationships in their internationalisation process. Moreover, recently Eberhard and Craig (2013) found a positive relationship between SMEs' internationalisation (proxied by export activities) and networks, which is measured in the form of seeking advice/information from outside sources. Given the above literature, we hypothesise that:

H1: SMEs that receive external advice/information have a higher likelihood of internationalisation.

\subsection{Interpersonal networks and internationalisation}

Interpersonal networks include all connections in which an individual has a direct relationship. In the context of firms, an interpersonal network can be defined as a group that consists of people from whom an owner-manager obtains advice, information and support (Dubini \& Aldrich, 1991). Therefore, interpersonal contacts are networks among people who are not only interlinked through social connections, but in which business and information exchange can also occur (Björkman \& Kock, 1995). Previous studies refer to interpersonal networks as social networks (Komulainen, Mainela \& Tahtinen, 2006; Zhou et al., 2007), social ties (Ellis, 2011), and informal and formal networks (Coviello \& Munro, 1997). These studies viewed interpersonal networks from the wider perspective, which integrates personal connections with businesses, government officials, and family and friends.

SNT suggests that the exchange of information occurs through interpersonal networks (Zhou et al., 2007). Previous empirical research confirms the role that is played by interpersonal networks in firms' internationalisation. Some studies show that interpersonal networks have a positive association with foreign market opportunities that promotes firms' internationalisation (Ellis, 2000; Ellis \& Pecotich, 2001; Zain \& Ng, 2006; Chandra, Styles \& can be a source of a firm's competitive advantage (Lavie, 2006). 
Wilkinson, 2009). Other studies note the negative role of interpersonal networks, such as the cost that is involved in participating in networks that might outweigh the benefits obtained from these networks (Mort \& Weerawardena, 2006). Moreover, it has been noted that when an individual has a high local network and fails to increase and expand their vision, they will be constrained in reaching the foreign information needed for internationalisation. Therefore, owners will be trapped 'in their local area preventing the search process outside the firm's own region' (Masciarelli, Laursen \& Principe, 2009, p. 19).

However, it can be argued that since SMEs lack internal managerial resources (Penrose, 1959), such as coordination and communication (Williamson, 1985), by developing networks and connections with international clients (Boehe, 2013) and clients in the home country, owner-managers will more likely gain significant information and the exchange of knowledge and resources will occur. Kingsley and Malecki (2004) argue that it is generally assumed that new and small firms are more likely to form and rely on local contacts based in their home markets rather than on foreign contacts. This is to be expected because it is the frequent face-to-face communications and relations that mean the most to small firms (Sweeney, 1987). As Nebus (2006, p. 616) puts it, 'despite recent advances in technology, people continue to prefer to converse with other people as the primary means of obtaining important information'.

Yiu, Lau and Bruton (2007) find that when local knowledge and information are exchanged with trade organisations and professional companies, a firm's internationalisation occurs, whereas Zhou et al. (2007) argue that home-based social networks act as the mediator that links firms' performance and internationalisation. Moreover, Zhang et al. (2016) point out that home-based network relationships reduce the risk associated with SMEs' international expansion. The principal idea behind this argument is that social network ties located in the home country are crucial for firms to explore foreign market opportunities and to expand their connections with international parties (Ellis \& Pecotich, 2001). In addition, a study by Mackinnon, Chapman and Cumbers (2004) regarding SMEs in the Aberdeen oil complex shows that 'extra-local' networks are an important source for exchanging knowledge and information. More specifically, one of their respondents stressed the role of these local networks in developing a presence in foreign markets. Interpersonal networks are based on trust and referrals (Oviatt \& McDougall, 2005) and these two factors represent key drivers that enable firms to respond to international market demands.

According to Brunetto and Farr-Wharton (2007), trust is a key moderator in the way owner-managers perceives the benefits from networks. For SMEs, it is a necessity to place 
trust in their relationships with others in order for them to trust the obtained information and knowledge (Kingsley \& Malecki, 2004). Trust and referral are higher when connections are based in the home market rather than international markets, because interactions will be faceto-face. As Boehe (2013) points out, through membership in trade association networks, local firms might obtain referrals to foreign buyers via these trade associations.

The existing literature mainly focuses on the role of foreign relationships in internationalisation. Although the literature advanced our knowledge regarding their role and importance in the internationalisation process of SMEs, it is surprising that the role of local interpersonal networks is not emphasised since early research suggested that internationalisation is strongly affected by relationships in the domestic markets (e.g. Johanson \& Mattsson, 1988; Ellis, 2000). According to Prashantham and Birkinshaw (2015), although a great deal is known regarding the important role of foreign country (i.e. non-local networks) networks and relationships in the internationalisation process, we still know little regarding the role of home market (local networks) networks that can either help or hinder SMEs' internationalisation (Fernhaber, Gilbert \& McDougall, 2008). Some research suggests that local networks are positively related to firms' international growth (e.g. Boehe, 2013) while others find that local relationships may hinder firms' expansion (e.g. Milanov \& Fernhaber, 2014) or they have no significant effects (Yu, Gilbert \& Oviatt, 2011). However, it can be argued that building and maintaining local networks and relationships with connections in the home market is beneficial for firms expanding across borders as input and output (Liesch, Wlech, Welch, McGaughey, Peterson \& Lamb, 2002). As an input, the information received from social and interpersonal networks may influence firms' internationalisation strategies (McAuley, 1993; Liesch \& Knight, 1999). From the outcome perspective, it is vital for firms seeking to internationalise to participate in networks and use their local interpersonal networks ${ }^{3}$ in order to obtain valuable information. Based on the above argument, we hypothesise that:

H2: Using local interpersonal networks increases the likelihood of SME internationalisation.

\footnotetext{
${ }^{3}$ Here we consider as local interpersonal networks the relationships formed within the firms' domestic market.
} 


\subsection{Formal and informal networks}

Interpersonal networks can further be differentiated according to the distinct source from which they are derived: formal and informal (Birley, 1985; Johannisson, 1987; Coviello \& Munro, 1997; Das \& Teng, 1997). Formal interpersonal networks consist of a set of 'formally specified relationships' among a group of differentiated individuals who must connect with each other in order to achieve a specific objective (Ibarra, 1993, p. 58). Kingsley and Malecki (2004, p. 72), in their study on the use of formal and informal networks by small manufacturers in the rural and urban counties of northern Florida, defined formal networks as 'intentionally formed group of small to medium-sized profit-oriented companies'. They argue that these types of connections share the same objectives, while Birley (1985) suggests that formal networks include connections with companies and individuals such as banks, lawyers, accountants, Chambers of Commerce and those involved in small business administration. Das and Teng (1997) suggest that formal networks include relationships with banks, accountants, lawyers, creditors, venture capitalists and trade associations. Formal networks are 'not usually in the business of diagnosing needs, but rather satisfying them by responding to a specific request' (Birley, 1985, p. 109).

Informal networks, on the other hand, consist of more flexible relationships and connections where the purpose of the interaction may not be related to work only, but could also be social or a combination of both (Ibarra, 1993). Kingsley and Malecki (2004, p. 72) suggest that informal networks are 'not bound by an explicit agreement' but rather by mutually supporting self-interests. Hence, informal networks include individuals such as family, friends, work colleagues, employers and business contacts (Birley, 1985; Das \& Teng, 1997). These contacts are more likely to listen to entrepreneurs than formal networks, and to offer guidance and advice on business issues even though they are less informed about the available opportunities in the marketplace.

Informal networks are considered an important source of information for SMEs because relationships with family and friends are inexpensive, regular and flexible (Kingsley \& Malecki, 2004). Hence, SMEs may function in a network of informal connections but turn to formal networks when the business complexity increases and owners' objectives are not being satisfied through information from friends. Previous studies suggest that entrepreneurs start by using their informal networks, and when their firms start to grow, they turn to formal networks (see Birley, 1985). Firms form relationships to control for uncertain situations in the environment surrounding them, to reduce the cost associated with searching for potential connections, and to obtain the resources and knowledge (Gulati \& Gargiulo, 1999) required 
for success and growth. Networks, which are beneficial during the start-up stage, may become limited in providing access to knowledge; this might affect the firm in a negative way (Lechner \& Dowling, 2003).

Therefore, owner-managers may change their network relationship types, which are based on unreflective decisions, to relationships based more on rational and logical behaviour in order to gain economic returns (Huggins, 2010). Hence, owner-managers may seek to form ties with other individuals or firms such as 'trade associations and research and development ventures' (Gulati \& Gargiulo, 1999, p. 1445) that have the capabilities and resources that can help them to adapt to the external constraints. These ties and relationships are characterised by a high level of trust and information exchange (Powell, 1990; Gulati \& Gargiulo, 1999). In time, these 'embedded' relationships (Granovetter, 1983) form a type of formal network that becomes a source for exchanging knowledge and resources.

Coviello and Munro (1997) find that both formal and informal interpersonal network relationships affect the internationalisation process in different aspects. However, their research does not differentiate between local and foreign networks. Hence, it is not clear which type of network is the driver for foreign market entry. Duchesneau and Gartner (1990), on the other hand, indicate that firms seeking professional advice are more likely to be successful than other firms. Moreover, Potts' (1997) results suggest that firms that use information provided by their external accountants are more successful in reaching their objectives. Watson's (2007) research finds that both formal networks, such as accountants and banks, and informal networks, such as family and friends, are related to a firm's survival. However, only formal networks are related to the firm's growth. Ojala's (2009) study shows that formal networks, such as suppliers operating in foreign markets, are the reason for firms entering foreign markets. However, firms with no direct relationships in the foreign markets use mediated networks, such as family and friends, to expand their businesses abroad.

Boter and Lundström's (2005) findings show that 50 per cent of the SMEs in their sample are in frequent contact with their banks, auditors and legal advisors. Moreover, they find that about one company in ten is in contact with the 'Swedish Trade Council' regarding exporting matters and 27 per cent receive benefits and achieve their objectives. Their results also show that the size of the company is related to seeking external advice/information. However, they argue that these results do not apply to the smallest micro firms. Larger SMEs, such as small and medium-sized firms, are likely to be more complex than micro firms and require different support and advice (Gino, Brooks \& Schweitzer, 2012; Mole et al., 2016) specifically related to internationalisation. 
The Small Business Survey, conducted by the Department for Business, Innovation and Skills (2012-2013), shows that 45 per cent of all SMEs employers sought external advice or information on matters related to their businesses. Their results indicate that medium-sized firms, 68 per cent, and small firms, 59 per cent, are more likely to use formal networking than micro firms. According to the survey's results, the most widely used sources of advice or networking were accountants, banks, lawyers and trade associations. It has been suggested that in order to adapt to the increasing and fast-changing global business environment, ownermanagers are required to seek advice and information from experts and specialists to make changes and take advantage of new opportunities (Fincham, 1999). Based on previous evidence and empirical results, we argue that formal interpersonal networks are more important in the internationalisation process of SMEs than informal networks. We also argue that formal networks are positively and significantly related to exporting in larger-sized SMEs rather than in smaller-sized ones. Hence, we hypothesise that:

H3: Using formal (informal) interpersonal networks increases the likelihood of larger (smaller)-sized SMEs' internationalisation.

\section{Data}

This paper uses data from the first wave of the UKLSBS (2015). This is the last in a series of annual and biennial small business surveys (SBS) dating back to 2003. The first wave of UKLSBS was commissioned by the Department of Business Innovation and Skills supported by a number of other department agencies. The survey is a large-scale telephone survey of 15,502 owners and managers of firms (those with up to 249 employees) in the UK, which allows us to provide new and more refined findings (BIS, 2016). The survey is based on a stratified sample within four nations: England, Wales, Scotland and Northern Ireland. Briefly, targets were set according to firm size, and within these groups, according to the sector (SIC, 2007). Moreover, for registered businesses with employees, between zero and four, an additional strata was set based on the legal status of the company. For registered firms, the Inter-Departmental Business Register (IDBR) source was employed. Finally, the Dun and Bradstreet database was used for unregistered companies with zero employees. Detailed information about the survey method and instruments can be found in the SBS report (2016).

Overall, the UKLSBS (2015) is a typical wide-range survey that provides a large quantity of information related to firms' characteristics, such as region, industry, the legal status of the firm, sector, the age of the firm and the perceived barriers to fulfilling business 
objectives. With regard to the key variables - exporting and networking - for this study, the data provide information on whether a firm exports goods and/or services outside the UK and whether owner-managers seek external advice/information on matters affecting their businesses. Therefore, the survey provides a relatively large sample size and rich information about internationalisation and networking activities and involvement.

\subsection{Measuring internationalisation through export propensity}

There are many different ways to operationalise internationalisation in the literature; some authors, for example, proxy this through foreign sales (e.g. Fernhaber \& Li 2012; FernándezOlmos, Gargallo-Castel \& Giner-Bagües, 2016) or established foreign operations (e.g. Musteen, Francis \& Datta, 2010). In this paper, however, we follow the majority of the literature on firm internationalisation and use export propensity as a proxy of internationalisation (e.g. Chetty \& Blankenburg-Holm, 2000; Cassiman \& Golovko, 2011; Eberhard \& Craig, 2013; Graves \& Shane, 2014). We follow Serra, Pointon and Abdou (2012, p. 216) who define export propensity 'as whether a firm exports to foreign markets', and we follow previous studies in measuring internationalisation by export propensity (Westhead et al., 2004; Cassiman \& Golovko, 2011; Boehe, 2013). The data provide information on whether a firm exports goods and/or services outside the UK. Specifically, the survey asks: 'In the past 12 months, did your business export any goods and/or services outside the UK?' The outcome variable is a binary variable taking the value of one if the firm sells outside the UK (i.e. export) and zero if not. Table 1 presents exporting activity by different firm size: micro firms (0-9 employees), small firms (10-49 employees) and medium-sized firms (50-249 employees). ${ }^{4}$ We find that about 22 per cent of UK SMEs are engaged in exporting their products and/or services. This figure is close to the one reported by Higón and Driffield (2010) who, using the small business survey (SBS) conducted in 2004, find that 23 per cent of SMEs in the UK are exporters. Comparing our results with more recent evidence, however, we find that our estimate is higher than the one reported in the 2014 SBS for SMEs, in which it is found that 19 per cent of all SME employers export goods, services or licensed products outside the UK.

\footnotetext{
${ }^{4}$ Due to missing values, the total number of observations included in the present study is reduced. Also, observations that reported 'don't know' for exporting and networking constructs were dropped, thereby leaving the sample size at 15,287 .
} 
Table 1: Exporting activity by firm size

\begin{tabular}{lcc}
\hline Firm Size & $\%$ & Obs. \\
\hline Micro & 16.42 & 8386 \\
Small & 25.92 & 4011 \\
Medium & 30.69 & 2890 \\
SMEs & 21.61 & 15287 \\
\hline
\end{tabular}

\subsection{Measuring external advice}

The survey also asks owner-managers whether they sought external advice/information. The fundamental question in the survey is: 'In the last 12 months, have you sought external advice or information on matters affecting your business?' The explanatory variable is also a binary variable taking the value of one if the owner-manager sought external advice/information, and zero if not. Table 2 presents seeking advice/information activity for each SME size band. Overall, we find that 36 per cent of all SMEs (including firms with zero employees) sought external advice/information on matters affecting their businesses. In particular, we find that 53 per cent of medium-sized firms sought external advice/information, followed by 41 per cent for small firms. The results imply that larger-sized SMEs are more likely to seek external advice/information than smaller-sized SMEs.

Table 2: Seeking external advice by firm size

\begin{tabular}{lcc}
\hline Firm size & $\%$ & Obs. \\
\hline Micro & 27.70 & 8386 \\
Small & 41.34 & 4011 \\
Medium & 53.36 & 2890 \\
All Firms & 36.13 & 15287 \\
\hline
\end{tabular}

\subsection{Measuring interpersonal networks}

Our construct of local interpersonal networks is measured as an index variable. The survey provides information regarding the source of advice/information. Owner-managers can choose at least one individual/organisation they have approached to gain external advice/information. We create our local interpersonal networks measurement as a binary variable taking the value of one if the owner-manager approached any individual/firm, and zero if they have not approached anyone. Finally, following Birley (1985) and Das and Teng (1997), we classify networks, according to their formality, into formal networks (i.e. accountants, banks, Chambers of Commerce, trade associations and solicitors) and informal 
networks (i.e. family, friends, business networks and work colleagues). Hence, a related measure is created to capture whether owner-managers approached both formal and informal networks, one of them or neither of them. In addition, the measure captures whether ownermanagers approached other types of networks (such as consultants, financial advisors and local enterprise partnerships). ${ }^{5}$ Figure 1 describes the undertaken network activity that is observed in the survey.

Figure 1: Network activity.

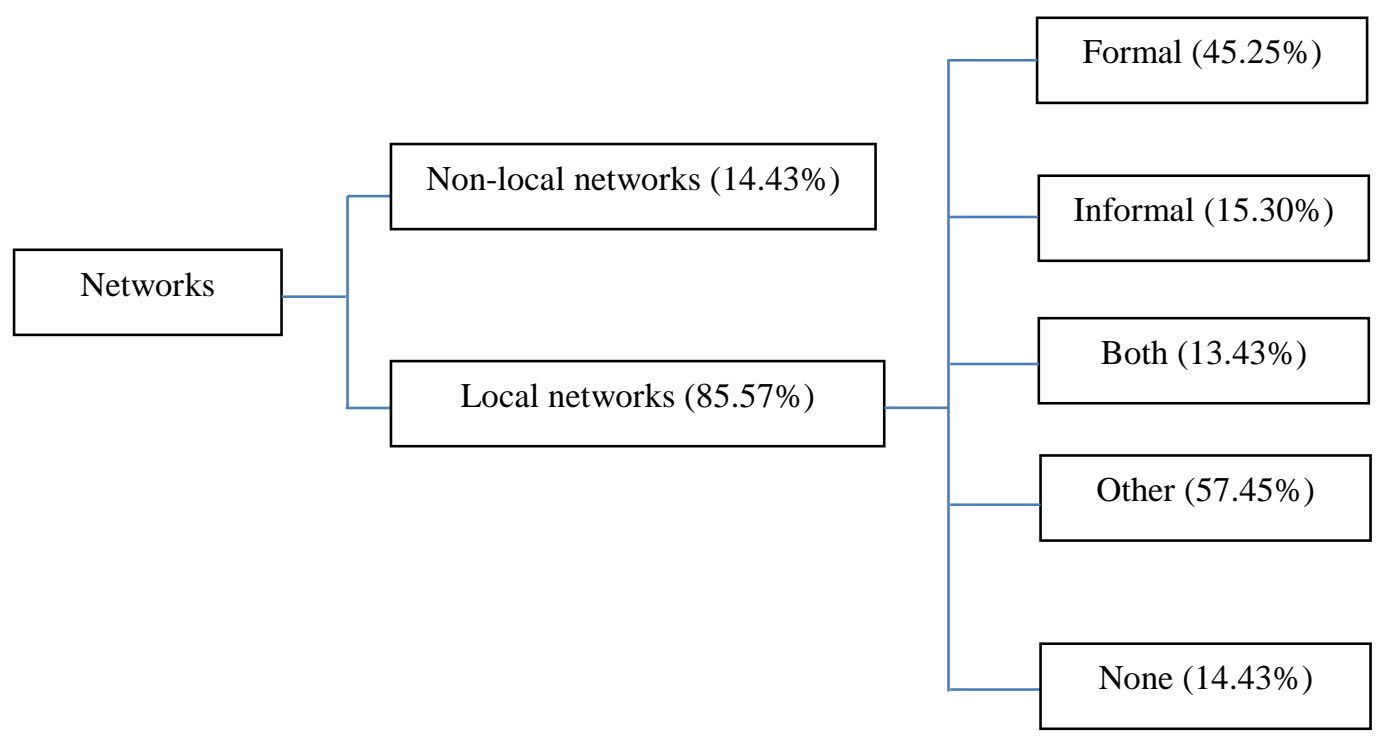

\subsection{Control variables}

In our model, we consider several control variables that influence SMEs' internationalisation, as previous empirical research shows. Specifically, we control for the 'size of the firm' measured by the natural logarithm of the number of employees. Previous research finds a positive but non-linear relationship between export and firm size (Roper \& Love, 2002). We also control for the 'age of the firm' measured by the number of years the business has been trading. Previous evidence provided conflicting results with respect to the effect of firms' age on exporting. From the theory point of view, it is expected that there exists a positive relationship between exporting and firms' age given that learning by doing may be the result of accumulated years of experience (Baldwin \& Rafiquzzaman, 1998). However, the opposite is also expected for younger firms that might be more active and aggressive. Some studies report that the age of the firm influences exporting in a positive way (e.g. Welch \& Weidersheim-Paul, 1980), while other studies report a negative influence (e.g. Das, 1994).

\footnotetext{
${ }^{5}$ The question on the types of local interpersonal networks allows for multiple responses per respondent.
} 
The study also controls for the 'legal status of the firm'. Empirical studies suggest that the legal status of the firm affects business decisions (Higón \& Driffield, 2010), especially in an international setting where exporting may be considered a risky decision. In addition, we control for the 'number of sites'. Roper and Love (2002) suggest, for example, that in the $\mathrm{UK}$, firms that belong to a business group are more likely to export since multiple numbers of sites allow the firm to overcome its resource constraints as required for exporting.

Finally, we control for the surrounding business environment, which is captured by the 'competition in the home market'. According to Miesenbock (1988), export behaviour may be affected by the domestic market conditions. Rammer and Schmiele (2009) find that competition in the home market is an obstacle to firms internationalising. Our models also include sectoral and regional dummies. ${ }^{6}$ Table 3 presents the variable definitions used in this study (for descriptive statistics, see Table A1 in the Appendix). Finally, in Table 4, we present the correlation between the variables.

\footnotetext{
${ }^{6}$ The survey does not provide any financial information about firm performance. However, it does provide selfreported information about the last year's turnover performance of a firm. We have included this variable in the model, and although in some cases the number of observations drops significantly, this does not alter the main conclusions of the paper (results are available upon request).
} 
Table 3: Variable definitions used in the models

\begin{tabular}{|c|c|}
\hline Variable & Definition \\
\hline Export & Whether the firm sells goods and/or services outside the UK (coded 1) or not. \\
\hline External advice & Whether the owner-manager has sought external advice/information (coded 1) or not. \\
\hline Local interpersonal networks & $\begin{array}{l}\text { Dummy variable = } 1 \text { if the owner-manager approached at least one source of advice from } \\
\text { the list available in the survey. }\end{array}$ \\
\hline Formal networks & $\begin{array}{l}\text { Dummy variable }=1 \text { if the owner-manager sought external advice from accountants, } \\
\text { banks, Chambers of Commerce, trade associations or solicitors. }\end{array}$ \\
\hline Informal networks & $\begin{array}{l}\text { Dummy variable }=1 \text { if the owner-manager sought external advice from family/friends, } \\
\text { business networks or work colleagues. }\end{array}$ \\
\hline Both networks & Dummy variable $=1$ if the owner-manager sought both formal and informal networks. \\
\hline Other networks & $\begin{array}{l}\text { Dummy Variable }=1 \text { if the owner-manager sought other types of networks (e.g. } \\
\text { consultants, financial advisors and local enterprise partnerships). }\end{array}$ \\
\hline No networks & Dummy variable $=1$ if the owner-manager did not seek any advice/information. \\
\hline Network location & $\begin{array}{l}\text { Dummy variable }=1 \text { if the owner-manager sought advice from a local network (i.e. } \\
\text { accountants, banks, friends, family etc.). } \\
\text { Dummy variable }=2 \text { if the owner-manager sought advice from a non-local network (i.e. } \\
\text { not from the list available in the survey). }\end{array}$ \\
\hline Network source & $\begin{array}{l}\text { Dummy variable }=1 \text { if the owner-manager sought non-local networks. } \\
\text { Dummy variable }=2 \text { if the owner-manager sought local formal networks. } \\
\text { Dummy variable }=3 \text { if the owner-manager sought local informal networks. } \\
\text { Dummy variable }=4 \text { if the owner-manager sought both types (i.e. formal and informal) of } \\
\text { local networks. } \\
\text { Dummy variable }=5 \text { if the owner-manager sought other types of local networks. } \\
\text { Dummy variable }=6 \text { if the owner-manager sought formal and other types of networks from } \\
\text { a local source. } \\
\text { Dummy variable }=7 \text { if the owner-manager sought informal and other types of local } \\
\text { networks. } \\
\text { Dummy variable }=8 \text { if the owner-manager sought both types (i.e. formal and informal) of } \\
\text { advice and other types of local networks. }\end{array}$ \\
\hline Size of the firm & Ln $(1+$ number of employees $)$. \\
\hline Age of the firm & $\begin{array}{l}\text { Broken down into age bands }(0-5 \text { years }=1,6-10 \text { years }=2,11-20 \text { years }=3,>20 \text { years }= \\
4) \text {. }\end{array}$ \\
\hline Legal status & Legal status of the business ( sole proprietorship $=1$, company $=2$, partnership $=3$ ). \\
\hline Sites & $\begin{array}{l}\text { Number of sites the business has }(1 \text { site }=1,2 \text { sites }=2,3 \text { sites }=3,4-10 \text { sites }=4,11+ \\
\text { sites }=5) \text {. }\end{array}$ \\
\hline Competition & $\begin{array}{l}\text { Dummy variable }=1 \text { if the major obstacle for the business is competition in the local } \\
\text { market. }\end{array}$ \\
\hline Regions & Location of the business (England $=1$, Scotland $=2$, Wales $=3$, Northern Ireland $=4$ ). \\
\hline Sectors & SIG 2007 (1-digit) classification. \\
\hline
\end{tabular}


Table 4: Correlation between key explanatory variables and dependent variable (export)

\begin{tabular}{|c|c|c|c|c|c|c|c|c|c|}
\hline & $(1)$ & (2) & (3) & (4) & (5) & (6) & (7) & (8) & (9) \\
\hline (1) Export & 1.000 & & & & & & & & \\
\hline (2) Advice/information & $0.121 *$ & 1.000 & & & & & & & \\
\hline (3) Local networks & $0.027 *$ & . & 1.000 & & & & & & \\
\hline (4) Formal networks & $0.028 *$ & . & $0.373^{*}$ & 1.000 & & & & & \\
\hline (5) Informal networks & -0.004 & . & $0.174 *$ & $0.363^{*}$ & 1.000 & & & & \\
\hline (6) Both networks & -0.005 & . & $0.161^{*}$ & $0.433^{*}$ & $0.926 *$ & 1.000 & & & \\
\hline (7) Other networks & 0.018 & . & $0.477^{*}$ & $-0.315^{*}$ & $-0.131 *$ & $-0.120 *$ & 1.000 & & \\
\hline (8) No networks & $-0.027 *$ & . & -1.000 & $-0.373 *$ & $-0.174 *$ & $-0.161 *$ & $-0.477 *$ & 1.000 & \\
\hline (9) Network location & $0.106^{*}$ & $0.933^{*}$ & -1.000 & $-0.373 *$ & $-0.174 *$ & $-0.161 *$ & $-0.477 *$ & $1.000^{*}$ & 1.000 \\
\hline (10) Network source & $0.111^{*}$ & $0.852 *$ & $0.632 *$ & $0.068^{*}$ & $0.322 *$ & $0.324 *$ & $0.869^{*}$ & $-0.623 *$ & $0.677 *$ \\
\hline
\end{tabular}

$* \mathrm{p}<0.05$

$n_{S M E S}=15287 ; n_{\text {micro }}=8386 ; n_{\text {small }}=4011 ; n_{\text {medium }}=2890$

\section{Empirical findings}

Since the variable we want to explain takes only two possible values ( 1 if the firm exports and 0 otherwise) we use probit regression in order to examine the potential relationships between exporting, external advice/information and local networks. In other words, probit is a binary choice model since it explains (0/1) dependent variable, and is an appropriate econometric technique that deals with problems associated with the linear probability model (for discussion see Gujarati 1995, pp. 552-570). ${ }^{7}$

Firstly, a latent variable that represents the propensity of a firm to export goods and services is defined $\left(E_{j}^{*}\right)$. We cannot observe $\left(E_{j}^{*}\right)$, but we can observe whether a firm $j$ exports through the following measurement equation:

$$
\begin{gathered}
E_{j}=\left\{\begin{array}{lll}
0 & \text { if } \quad E_{j}^{*} \leq 0 \\
1 & \text { if } \quad E_{j}^{*}>0
\end{array}\right. \\
E_{j}^{*}=X_{j} b_{j}+A_{j} \vartheta+N_{j} \delta+e_{j}, e \sim N\left(0, \sigma^{2}\right)
\end{gathered}
$$

where $A$ and $N$ are the indicator variables for whether the firm has sought external advice/information and a network, respectively. $X$ is the vector of firm characteristics for firm $j . b, \vartheta$ and $\delta$ are the parameters to be estimated. The model is estimated by maximum likelihood techniques (Stock \& Watson, 2012).

\footnotetext{
${ }^{7}$ To check whether the results are robust to a different modelling approach, we also use a logit model, which is another model commonly used whenever the dependent variable is binary. Specifically, logit uses the cumulative standard logistic distribution whereas probit uses the cumulative standard distribution. However, the results from the logit model are similar to those reported from the probit model, and thus are not reported here.
} 


\subsection{Full sample analysis}

Table 5 presents the marginal effects of the probit estimations. We find that seeking external advice/information increases the likelihood of SMEs exporting outside their home country (this is found to increase the probability by 6.7 percentage points) ${ }^{8}$ The results also show that local interpersonal networks are positively associated with firms' exporting activities (with the marginal effect being 0.034). Hence, the overall sample results provide strong support for both $H 1$ and $H 2$.

When the model includes detailed information about the types of local interpersonal network formality, the results show that formal networks are positively and directly related to SMEs' exporting. This implies that seeking advice/information from formal sources, such as accountants and banks, increases the likelihood of firms exporting by nearly 3 percentage points. Moreover, we find that other types of networks, such as financial advisers, are positively associated with internationalisation. ${ }^{9}$

The results in Table 5 show that local and non-local networks increase the likelihood of firms exporting. In particular, the effect of the former source is found to be nearly twice the magnitude of the latter's effect $\left(x^{2}(1)=3.33\right.$ and Prob. $\left.=0.06\right)$.

We also test the association between network source and exporting. The results in Table 5 suggest that seeking advice/information from all local networks, with the exception of informal networks, increases the likelihood of firms exporting. We test whether these variables are statistically significantly different from each other. The results imply that nonlocal networks are statistically different from local formal networks $\left(x^{2}(1)=3.00\right.$, Prob. $=$ 0.079).

The results also show that a non-local network is statistically different from local formal \& other networks $\left(x^{2}(1)=4.05\right.$, Prob.=0.044) and that a non-local network is statistically different from local informal $\&$ other networks $\left(x^{2}(1)=3.14\right.$, Prob. $\left.=0.076\right)$.

\footnotetext{
${ }^{8}$ We also estimate the average treatment effect on the treated using the nearest neighbour estimator. The results suggest that for firms that have received external advice/information, the external advice/information has caused the probability of exporting to be 6.7 percentage points higher than it would have been otherwise.

${ }^{9}$ We test to see whether formal networks and other types of networks are statistically different from each other. The results report that $x^{2}(1)=0.30$ and Prob. $=0.58$; hence, formal networks and other types of networks are not significantly different from one another.
} 
Table 5: The association between networks and SME exporting (full sample estimates)

\begin{tabular}{|c|c|c|c|c|c|}
\hline \multirow{2}{*}{$\begin{array}{l}\text { Sample } \\
\text { Probit Regression }\end{array}$} & \multicolumn{5}{|c|}{ All Firms } \\
\hline & $\mathrm{dy} / \mathrm{dx}$ & $\mathrm{dy} / \mathrm{dx}$ & $\mathrm{dy} / \mathrm{dx}$ & $\mathrm{dy} / \mathrm{dx}$ & $\mathrm{dy} / \mathrm{dx}$ \\
\hline \multirow[t]{2}{*}{ Advice/information } & $0.067 * * *$ & & & & \\
\hline & 0.006 & & & & \\
\hline \multirow[t]{2}{*}{ Local networks } & & $0.034 * *$ & & & \\
\hline & & 0.016 & & & \\
\hline \multicolumn{6}{|l|}{$\begin{array}{l}\text { Network Formality } \\
\text { (Base category: No network) }\end{array}$} \\
\hline \multirow[t]{2}{*}{$\underline{\text { Formal networks }}$} & & & $0.031 * *$ & & \\
\hline & & & 0.014 & & \\
\hline \multirow[t]{2}{*}{$\underline{\text { Informal networks }}$} & & & 0.055 & & \\
\hline & & & 0.049 & & \\
\hline \multirow[t]{2}{*}{$\underline{\text { Both networks }}$} & & & -0.060 & & \\
\hline & & & 0.043 & & \\
\hline \multirow[t]{2}{*}{ Other networks } & & & $0.022 *$ & & \\
\hline & & & 0.012 & & \\
\hline \multicolumn{6}{|l|}{$\begin{array}{l}\text { Network Location } \\
\text { (Base category: No network) }\end{array}$} \\
\hline \multirow[t]{2}{*}{$\underline{\text { Local networks }}$} & & & & $0.072 * * *$ & \\
\hline & & & & 0.007 & \\
\hline \multirow[t]{2}{*}{ Non-local networks } & & & & $0.046 * * *$ & \\
\hline & & & & 0.015 & \\
\hline \multicolumn{6}{|l|}{$\begin{array}{l}\text { Network Source } \\
\text { (Base category: No network) }\end{array}$} \\
\hline \multirow[t]{2}{*}{$\underline{\text { Non-local networks }}$} & & & & & $0.046 * * *$ \\
\hline & & & & & 0.015 \\
\hline \multirow[t]{2}{*}{$\underline{\text { Formal local networks }}$} & & & & & $0.081 * * *$ \\
\hline & & & & & 0.014 \\
\hline \multirow[t]{2}{*}{ Informal local networks } & & & & & 0.070 \\
\hline & & & & & 0.059 \\
\hline \multirow[t]{2}{*}{$\underline{\text { Both local networks }}$} & & & & & $0.064 * * *$ \\
\hline & & & & & 0.021 \\
\hline \multirow[t]{2}{*}{$\underline{\text { Other local networks }}$} & & & & & $0.066 * * *$ \\
\hline & & & & & 0.010 \\
\hline \multirow[t]{2}{*}{$\underline{\text { Formal \& other local networks }}$} & & & & & $0.092 * * *$ \\
\hline & & & & & 0.017 \\
\hline \multirow[t]{2}{*}{ Informal \& other local networks } & & & & & $0.177 * * *$ \\
\hline & & & & & 0.079 \\
\hline \multirow[t]{2}{*}{ Both \& other local networks } & & & & & $0.093 * * *$ \\
\hline & & & & & 0.026 \\
\hline Controls & Yes & Yes & Yes & Yes & Yes \\
\hline Log Likelihood & -6325.998 & -2617.347 & -2615.875 & -6324.321 & -6322.142 \\
\hline Chi 2 & $3306.64(32)$ & $1340.52(32)$ & $1343.46(35)$ & $3310.00(33)$ & $3314.36(39)$ \\
\hline Obs. & 15287 & 5523 & 5523 & 15287 & 15287 \\
\hline
\end{tabular}

Notes:

All models control for variables mentioned before (results are available upon request).

For robustness check, we also estimate the model using a logit model, but the results are similar (results are available upon request).

Values in italics are standard errors.

$* * * \mathrm{p}<0.01, * * \mathrm{p}<0.05, * \mathrm{p}<0.1$ 


\subsection{Subsample analysis}

In Table 6, we present the results for different SME groups (i.e. micro, small, and medium). The results show that seeking advice/information increases the likelihood of all sizes of firms exporting. However, the results imply that local interpersonal networks are not significant in micro, small and medium-sized firms. When differentiating between different types of networks, our third hypothesis proposes a positive and significant relationship between formal networks and exporting in larger SMEs. In contrast, it also proposes that informal networks can play an important role for smaller SMEs. The results suggest that formal networks are positive and significant in small and medium-sized firms but not in micro firms. However, we find no association between informal networks and exporting for both smaller and larger SMEs. Overall, these results provide partial empirical support for H3. Moreover, the effects of other types of networks are positive and statistically significant in mediumsized firms. We found the magnitude of the effect to be similar to the one reported for formal networks $\left(x^{2}(1)=0.00\right.$, Prob. $\left.=0.98\right)$. The results also show that local and non-local networks increase the likelihood of micro and small firms exporting. However, only local networks are significant and positive in medium-sized firms. Therefore, for medium-sized firms, seeking local interpersonal networks increases the likelihood of these types of firms exporting and internationalising. We test whether the effects of local and non-local networks are statistically different from one another in micro and small firms. The results show that for micro and small firms, local and non-local networks are not statistically different $\left(x^{2}(1)=\right.$ 1.27, Prob. $=0.259$ and $x^{2}(1)=2.30$, Prob. $=0.129$, respectively). 
Table 6: The association between networks and SME exporting by firm size (subsample estimates)

\begin{tabular}{|c|c|c|c|c|c|c|c|c|c|c|c|c|c|c|c|}
\hline Sample & & & Micro & & & & & Small & & & & & Medium & & \\
\hline Probit Regression & $\mathrm{dy} / \mathrm{dx}$ & $\mathrm{dy} / \mathrm{dx}$ & $\mathrm{dy} / \mathrm{dx}$ & $\mathrm{dy} / \mathrm{dx}$ & $\mathrm{dy} / \mathrm{dx}$ & $\mathrm{dy} / \mathrm{dx}$ & $\mathrm{dy} / \mathrm{dx}$ & $\mathrm{dy} / \mathrm{dx}$ & $\mathrm{dy} / \mathrm{dx}$ & $\mathrm{dy} / \mathrm{dx}$ & $\mathrm{dy} / \mathrm{dx}$ & $\mathrm{dy} / \mathrm{dx}$ & $\mathrm{dy} / \mathrm{dx}$ & $\mathrm{dy} / \mathrm{dx}$ & $\mathrm{dy} / \mathrm{dx}$ \\
\hline Advice/information & $0.059 * * *$ & & & & & $0.089 * * *$ & & & & & $0.044 * * *$ & & & & \\
\hline & 0.008 & & & & & 0.013 & & & & & 0.017 & & & & \\
\hline Local networks & & 0.027 & & & & & 0.048 & & & & & 0.051 & & & \\
\hline & & 0.073 & & & & & 0.030 & & & & & 0.039 & & & \\
\hline Network Formality & & & & & & & & & & & & & & & \\
\hline (Base Category: No networks) & & & & & & & & & & & & & & & \\
\hline Formal networks & & & 0.019 & & & & & $0.054 * *$ & & & & & $0.061 * *$ & & \\
\hline & & & 0.050 & & & & & 0.028 & & & & & 0.030 & & \\
\hline Informal networks & & & 0.054 & & & & & -0.035 & & & & & 0.026 & & \\
\hline & & & 0.138 & & & & & 0.118 & & & & & 0.111 & & \\
\hline$\underline{\text { Both networks }}$ & & & -0.067 & & & & & 0.007 & & & & & -0.015 & & \\
\hline & & & 0.189 & & & & & 0.132 & & & & & 0.113 & & \\
\hline Other networks & & & 0.013 & & & & & 0.015 & & & & & $0.059 * *$ & & \\
\hline & & & 0.036 & & & & & 0.024 & & & & & 0.028 & & \\
\hline $\begin{array}{l}\text { Network Location } \\
\text { (Base category: No network) }\end{array}$ & & & & & & & & & & & & & & & \\
\hline$\underline{\text { Local networks }}$ & & & & $0.064 * * *$ & & & & & $0.098^{* * * *}$ & & & & & $0.048^{* * * *}$ & \\
\hline & & & & 0.009 & & & & & 0.015 & & & & & 0.017 & \\
\hline Non-local networks & & & & $0.043^{* *}$ & & & & & $0.057 * *$ & & & & & 0.008 & \\
\hline & & & & 0.020 & & & & & 0.030 & & & & & 0.038 & \\
\hline Network Source & & & & & & & & & & & & & & & \\
\hline (Base category: No network) & & & & & & & & & & & & & & & \\
\hline Non-local networks & & & & & $0.043 * *$ & & & & & $0.057 * *$ & & & & & 0.008 \\
\hline & & & & & 0.020 & & & & & 0.030 & & & & & 0.038 \\
\hline Formal local networks & & & & & $0.072 * * *$ & & & & & $0.134 * * *$ & & & & & 0.034 \\
\hline & & & & & 0.018 & & & & & 0.032 & & & & & 0.030 \\
\hline Informal local networks & & & & & 0.082 & & & & & 0.019 & & & & & -0.003 \\
\hline & & & & & 0.075 & & & & & 0.119 & & & & & 0.122 \\
\hline Both local networks & & & & & $0.055^{* *}$ & & & & & $0.118^{* * * *}$ & & & & & 0.004 \\
\hline & & & & & 0.027 & & & & & 0.046 & & & & & 0.050 \\
\hline Other local networks & & & & & $0.066 * * *$ & & & & & $0.087^{* * * *}$ & & & & & 0.035 \\
\hline & & & & & 0.014 & & & & & 0.020 & & & & & 0.233 \\
\hline Formal \& other local networks & & & & & $0.063^{* * *}$ & & & & & $0.130^{* * * *}$ & & & & & $0.095 * * *$ \\
\hline & & & & & 0.025 & & & & & 0.037 & & & & & 0.035 \\
\hline Informal \& other local networks & & & & & $0.148^{* *}$ & & & & & 0.189 & & & & & 0.446 \\
\hline & & & & & 0.084 & & & & & 0.355 & & & & & 0.152 \\
\hline Both \& other local networks & & & & & $0.059 * *$ & & & & & $0.096^{* *}$ & & & & & $0.156^{* * * *}$ \\
\hline & & & & & 0.034 & & & & & 0.049 & & & & & 0.066 \\
\hline Controls & Yes & Yes & Yes & Yes & Yes & Yes & Yes & Yes & Yes & Yes & Yes & Yes & Yes & Yes & Yes \\
\hline Log Likelihood & -3215.811 & -1092.482 & -1092.109 & -3215.170 & -3214.423 & -1771.976 & -788.737 & -787.898 & -1170.815 & -1769.441 & -1220.795 & -664.840 & -661.984 & -1220.228 & -1216.76 \\
\hline Chi 2 & $1058.30(32)$ & $300.31(32)$ & $301.06(35)$ & $1059.58(33)$ & $1061.07(39)$ & $1047.12(31)$ & 483.55 (29) & $485.23(32)$ & $1049.44(32)$ & 1052.19 & $1122.44(32)$ & 545.08 & $550.79(32)$ & $1123.57(33)$ & $1130.51(39)$ \\
\hline Obs. & 8386 & 2323 & 2323 & 8386 & 8386 & 4011 & 1644 & 1644 & 4011 & 4011 & 2890 & 1446 & 1446 & 2890 & 2890 \\
\hline
\end{tabular}

All models control for variables mentioned before (results are available upon request). Values in italics are standard errors. For robustness check, we also estimate the model using a logit model, but the results are similar (result are available upon request).

*** $\mathrm{p}<0.01,{ }^{* *} \mathrm{p}<0.05,{ }^{*} \mathrm{p}<0.1$ 
Furthermore, the results in Table 6 show that for micro firms, seeking local external advice/information from all local networks, with the exception of informal networks, increases the likelihood of micro firms' internationalisation and exporting their products and services. The results also suggest that seeking external advice/information from non-local networks increases the likelihood of micro firms exporting. We test whether these types of advice sources are statistically different from each other. The results imply that for micro firms these variables are not statistically different from one another $\left(x^{2}(6)=2.74\right.$, Prob. $=$ 0.841). By testing the association between the source of local networks and small firms' exporting, the results suggest that seeking external advice from all local networks, with the exception of informal networks and the combination of informal \& other types of networks, is significant and positive in small firms' internationalisation. The results also imply that for small firms, seeking non-local networks increases the likelihood of exporting. We test whether these variables are statistically different. The results show that non-local networks and local formal networks are statistically different from each other. The results also report that $x^{2}(1)=3.42$ and Prob. $=0.064$, hence we accept the null hypothesis and conclude that for small firms, seeking external advice/information from a local formal network is different from seeking external advice/information from a non-local network. For medium-sized firms the results are different from other SME groups. The results show that only a combination of networks (i.e. formal \& other, both \& other) is significant and positive in medium-sized firms' internationalisation. We test whether these two sources are statistically significantly different from each other. The results show that $x^{2}(1)=0.73$ and Prob. $=0.393$. Hence, we conclude that these two sources are not statistically significantly different. Moreover, the results show that non-local networks are not significant and are not related to medium-sized firms. This suggests that medium-sized firms rely on local networks for their internationalisation rather than on foreign networks located in the international market.

\section{Discussion}

\subsection{Seeking advice/information}

This paper has empirically examined the relationship between networks and SMEs' internationalisation. First, we examined the direct relationship between networks in the form of seeking external advice/information and SMEs' internationalisation in the form of exporting. The estimation results have shown that seeking external advice/information is 
positively and significantly related to SMEs' internationalisation in the overall SME sample, as well as in split samples of firms (i.e. micro, small and medium-sized firms). This is consistent with previous empirical research in IB and small business fields that found that networks are important in the internationalisation process of firms (Zhou et al., 2007; Ge \& Wang, 2013; Oparaocha, 2015; Hånell \& Ghauri, 2016; Stoian et al., 2016; Rosenbaum, 2017). Hence, by establishing a network position, SMEs gain significant advantages, such as 'learning and developing trust and commitment', necessary for internationalisation (Ghauri et al., 2014, p. 580). This is to be expected since SMEs are encouraged by the government to seek external advice/information and support from outside sources (Mole et al., 2016). External advice and information from outsiders increases firms' strategic knowledge and competitive advantage (Bennett \& Robson, 2003).

When the overall SME sample is split between micro, small and medium-sized firms, the analysis reveals that networks are positively and directly related to firms' internationalisation in all SME groups. Although previous empirical studies did not differentiate between SME groups, we argue alongside Mole et al. (2016) that external advice/information, particularly in the smallest and youngest firms, is significant because firms can overcome information and knowledge gaps. Our results are consistent with the RBV theory of the firm, which implies that external advice is sought by firms in the search for new markets through exporting and innovation (Bennett \& Robson, 2003). Johnson et al. (2007, p. 1995) argue that firms that have plans to grow, in terms of 'expansion into new geographical markets, are significantly more likely' to use networks. Since SMEs face different types of internal and external export barriers (Leonidou, 2004), it is more beneficial for owner-managers to engage in networks and seek external advice/information on matters related to their businesses in order for them to grow and internationalise.

\subsection{Local interpersonal networks}

Second, we examined whether local interpersonal network relationships are associated with SMEs' exporting. The estimated results show that there is a positive and direct association between owner-managers' local interpersonal networks and exporting. Our results are consistent with previous empirical research indicating that local interpersonal networks have a positive effect on firms' internationalisation (Manolova et al., 2010; Eberhard \& Craig, 2013; Zhang et al., 2016). Specifically, building on the social network theory of internationalisation, we provide new evidence regarding the role of local interpersonal 
networks and SMEs internationalisation. Contrary to previous studies (e.g. Ellis \& Pecotich, 2001; Ojala, 2009; Francioni, Vissak \& Musso, 2017), which found that foreign networks are significant, our results suggest that local networks are more effective for SMEs' internationalisation. Perhaps this is partly because small firms value the frequent face-to-face interaction more, hence their network connections are home-based (Kingsley \& Malecki, 2004). Local relationships developed in the home market can help owner-managers to understand the international market through other firms' international experiences (Zhang et al., 2016). Since owner-managers place great importance on meeting and communicating with other individuals, which will result in 'business know-who' and 'business know-how' (Peterson \& Rondstadt, 1986), our results show that participation in local networks will affect SMEs' internationalisation in a positive way (Masciarelli et al., 2009). In addition, we argue that local interpersonal network relationships are based on trust, referrals, mutual experience (McGrath, Vance \& Gray, 2003) and credibility.

Trust and referrals can act as facilitators for firms to increase their capabilities and respond to market demands (Oviatt \& McDougall, 2005). By developing relationships in the home market, and working with other individuals in the same network, credibility and trust will be developed in a gradual way (Larson, 1992; Zhang et al., 2016). Therefore, it seems rational for entrepreneurs and small firms that are active internationally, or looking to expand their businesses abroad, to rely more on the 'readily available' local networks to gain information and benefits (Zhou et al., 2007). Credibility and trust can be developed through network relationships between members (Turnbull, Ford \& Cunningham, 1996), especially in the home market. One may suggest, however, that local networks may not always offer firms great advantages related to their strategy and growth because local networks are embedded in local settings and may lack the appropriate international connections. However, we argue that knowledge exchange and information can be obtained from local sources such as trade associations and professional bodies, which will provide significant assistance for firms to internationalise (Yiu et al., 2007). At the local level, firms may obtain referrals through their memberships in local networks such as industry associations (Boehe, 2013). Hence, export opportunities, via interpersonal connections based in the home market, will develop. This will result in reducing export barriers through local reachability since local reachability increases international reachability (Leonidou, 2004).

When examining the effect of local interpersonal networks, and the effect of non-local interpersonal networks, on SMEs' exporting, the results imply that, compared to no networks at all, local and non-local interpersonal networks are positively and directly related to SMEs' 
internationalisation. Our results are in line with those of Anderson, Evers and Griot (2013), indicating that both local and non-local networks influence firms' internationalisation, but in different ways. We argue that local networks, especially those formed with banks and consultants, have a greater effect on firms' internationalisation, which confirms our previous results. When the overall SME sample is split between micro, small and medium, the results imply that local and non-local networks are significant in micro and small firms' internationalisation only. However, for medium firms, local networks are important for their internationalisation. This is to be expected since owner-managers of smaller SMEs have specific requirements and they need a greater level of external advice and support (Robson \& Bennett, 2000); therefore, they seek local and non-local advice.

\subsection{Network formality}

Third, we examined the effect of different types of network formality on SMEs' internationalisation. By following Birley (1985) and Das and Teng (1997), we classified networks into formal networks (i.e. accountants, banks, Chambers of Commerce, trade associations and solicitors) and informal networks (i.e. family, friends, business networks and work colleagues). Contrary to some previous studies (Coviello \& Munro, 1995; Coviello, 2006; Westphal, Boivie \& Chng, 2006; Ojala, 2009), we found that only formal networks are positive and significant in SMEs' exporting. Our results are consistent with Watson's (2007) study, which is based on a large longitudinal database and shows that there is a significant positive relationship between formal networks, such as accountants, and firms' growth and survival.

Firms' growth is associated with the owner's formal, rather than informal, networks. The distribution of information is more likely to come from weak ties rather than strong ones such as those with family and friends (Granovetter, 1983). ${ }^{10}$ Formal connections provide less redundant information that has a greater market value for firms, especially those seeking to internationalise (Rosenbaum, 2017). Therefore, owner-managers use formal networks in order to obtain resources and advice and achieve their objectives, which would 'not be possible due to cost constraints and economies of scales if the enterprise operated in isolation' (Dean, Holmes \& Smith, 1997, p. 78). Although most small firms use several different sources of advice networks, specialist professionals are the most valuable and important source of advice for small firms (Bennett \& Robson, 1999). Hence, we argue, alongside Tang (2011) that not all types of networks necessarily enable internationalisation.

\footnotetext{
${ }^{10}$ In this respect, our results show that formal types of networks are more significant in providing information than informal ones, supporting Granovetter's (1983) strength of weak ties theory.
} 
When the overall SME sample is split between micro, small and medium-sized firms, our results imply that formal networks are significant and positively related to firms' internationalisation in small and medium-sized firms only. Although previous research did not empirically differentiate between SME groups to indicate which types of network formality are closely associated with internationalisation, our results are in line with those of Mole et al. (2016, p. 2), thereby implying that the tendency to use formal advice networks is at a 'threshold of around ten employees'. According to Boter and Lundström (2005), the argument that SMEs have limited and weak resources and are in need of external advice and networks does not apply to the smallest micro firms. Businesses with more than ten employees (i.e. small and medium firms) become more complex when they increase in size. However, they are still small enough to employ more staff in order to fill in the required skills and knowledge internally. According to Saridakis, Mole and Hay (2012), the size and age of the firm are positive and directly related to firms' growth. Firms' growth and complexity tend to increase more rapidly with size for older firms and with age for larger firms. Based on this argument, small and medium-sized firms are required to form relationships with different kinds of expertise in order to fulfil their objectives, grow and internationalise their business.

Our results imply that SMEs are more likely to be dependent on networks consisting of entrepreneurs' social networks. However, when the size of the firm starts to grow, ownersmanagers will change their networking behaviour and move to more calculative networks based on logical behaviour in order to obtain economic returns that will benefit their firms (Huggins, 2010) and their internationalisation.

Our results show that micro firms tend not to participate in any types of networks, which can be explained by the following reasons. First, owner-managers of micro firms suffer from imperfect information because of their size and limited resources, which affect their awareness of the available external networks (Bennett, 2008). Even when entrepreneurs are aware of these types of networks and their advantages, they might be reluctant to use them because of their reliability and value (Spence, 1973). Second, the costs associated with these types of networks might be another reason for owner-managers being reluctant to use them. It is also generally agreed that being a small firm means that it is more complex and difficult to gain the recognition and trust of a prospective network (Zahra, 2005).

Similarly, it has been pointed out that many small firms are independent and tend to operate in isolation (Curran, Jarvis, Blackburn \& Black, 1993). Owner-managers of these types of firms view themselves as independent and do not trust the 'outside' (De Vries, 2000); hence, they are more likely not to seek external advice on matters related to their 
businesses. Finally, the legal status of firms affects their strategic decisions, such as those related to exporting and internationalisation, since these decisions are viewed as risky ones (Higón \& Driffield, 2010). According to Saridakis et al. (2012), being a limited company has a significant effect on a firm's performance. Therefore, being a limited company, sole trader or partnership will also affect how firms participate in networks for internationalisation purposes. Hence, these factors can discourage micro firms from networking and seeking advice/information on matters related to their businesses.

\subsection{Network source}

Finally, we tested for the effect of the source of the advice obtained locally. The results imply that seeking local advice from all types of networks, except for informal networks, is significant and has a positive and direct effect on all firms' internationalisation. This supports our previous results indicating that formal and other types of networks are significant for SMEs' internationalisation. Moreover, this confirms our previous results indicating that participating in networks will affect firms' internationalisation in a positive way because firms can overcome their limited resources and gain more knowledge and information through networks (Mole et al., 2016). Although our results imply that local informal networks are not significant and are not related to firms' internationalisation, our findings show that when informal and other types of networks are sought together, the likelihood of firms internationalising will increase. This is to be expected since informal networks are generally expected to be less informed about the available opportunities in the marketplace (Birley, 1985) and they generally provide redundant information (Rosenbaum, 2017). Hence, ownermanagers tend to seek other types of networks, such as consultants and local enterprise partnerships, alongside informal networks.

When the overall SME sample is split between micro, small and medium-sized firms, the results imply that for micro firms, all types of advice networks, with the exception of informal networks, are significant and have a positive effect on internationalisation. However, the results show that when informal networks are used with other types of networks simultaneously, micro firms are more likely to export. For small firms, the results show that all types of networks, with the exception of informal networks and the combination of informal and other networks, are insignificant and have no relationship with small firms' internationalisation. On the other hand, for medium-sized firms, our results show that when one type of network is sought, the effect of networks on internationalisation is insignificant. However, when medium-sized firms seek all types of networks, the results are positive and 
affect internationalisation directly and in a positive way. Hence, medium-sized firms tend to seek all types of advice networks, such as accountants, consultants and colleagues, simultaneously. This is to be expected since medium-sized firms are more complex than small and micro firms, and they operate in a more competitive environment than the former. Therefore, seeking advice from consultants, for instance, who provide firms with knowledge in more efficient ways because they are more informed about the surrounding industries and markets (Anand, Glick \& Manz, 2002), along with consulting with work colleagues, who might have international experience, is more beneficial for medium-sized firms' internationalisation. The results imply that larger SMEs' networking behaviour for internationalisation purposes is different from that of smaller SMEs.

Moreover, the results show that firms' networking behaviour for internationalisation purposes changes with the size of the firm. Our results show that when the size of the firm increased from micro to small, the effect of the network increased. This is to be expected since previous studies have shown that firms with an objective to grow are more likely to seek formal advice/information for networking than firms with no plans to grow (Johnson et al., 2007; Mole et al., 2016). Our results also show that when the size of the firm increased from small to medium, the effect of most of the network sources diminished and disappeared. Our results are in line with Watson's (2007) argument implying that the relationship between networking and SMEs' growth is a non-linear one. The results imply that the relationship between networking and the size of the firm is an inverted relationship. Although it is beneficial to expect that a reasonable level of networking will affect firms in a positive way, it is also reasonable to expect that an extreme level of networking might produce inverse effects for firms. Therefore, our results suggest that micro and small firms tend to participate in one advice network for the purpose of internationalisation. However, medium-sized firms tend to participate in more than one network for their internationalisation purposes.

To sum up, our paper makes three important contributions to IE, IB and small business literature by focusing on SME internationalisation from IE, interpersonal networks from IB and exporting from small business perspectives. First, we contribute to the field by providing empirical evidence regarding the role of formal interpersonal networks - obtained from the local market where the firm operates - in the internationalisation process of SMEs. Second, given the large data set, we examine the link between networking behaviour and exporting within different-sized SMEs. This allows us to observe differences between largersized SMEs and smaller ones, which can be hidden when data is aggregated. Our results, for example, show that micro firms are reluctant to use networks in the form of seeking 
advice/information from outside sources such as accountants and trade associations. Finally, we directly respond to the call for more focused research on the link between interpersonal networks and the internationalisation process, especially for SMEs. By doing so, we add to the literature regarding the role that owner-managers can play in forming networks through seeking advice/information and show how this in turn affects internationalisation.

\section{Implications and limitations}

Our findings have important implications for practice and research. For practice, and in contrast to previous studies, which have emphasised the role of foreign networks in the internationalisation process of small and medium-sized firms (e.g. Ojala, 2009; Francioni et al., 2017), we suggest that SMEs should focus on home market relationships and networks (Zhang et al., 2012; Eberhard \& Craig, 2013). In addition, we suggest that focusing on gaining advice/information from professionals and experts in the home market will benefit SMEs a great deal (Mole et al., 2016), and will provide knowledge and information, especially on matters related to their internationalisation. Moreover, in contrast to previous studies that found that formal and informal networks are important in the internationalisation process of SMEs (e.g. Coviello, 2006; Ojala, 2009), we suggest that the focus should be on the formal types of networks such as accountants, banks, Chambers of Commerce and solicitors. Information and advice obtained from these types of networks will enable ownermanagers to gain advantages in the form of economic returns. Our results suggest that when the size of firms increases from micro to small or medium, they tend to change their networking behaviour from social behaviour to a more calculative behaviour based on a logical rationale in order to obtain economic returns (Huggins, 2010). Our findings regarding the use of formal networks by only small and medium-sized firms reveal concerns for policymakers. Although the government in the UK is encouraging SMEs to seek advice/information and to participate in networks, micro firms and firms with no employees are still reluctant to use these services. This is partly because of the cost associated with participating in such networks, and partly because of trust and entrepreneurs' independence. Hence, the government should encourage greater use of these networks by making these SMEs aware of their availability. Our findings also suggest that the nature of medium-sized firms is different from that of micro and small firms since medium-sized firms operate in a more competitive environment; hence, medium-sized firms should focus their networking on the home market and seek out all types of networks in order to gain advantages and internationalise. 
There are, of course, limitations to the analysis in this study that may merit further examination. Using a cross-sectional data set, our results suggest an association between formal interpersonal networks and SMEs' internationalisation. However, using panel data and longitudinal research to examine the effects of time on forming network relationships for internationalisation purposes is strongly recommended. In addition, and due to the available data from the UKLSBS (2015), our measurement of internationalisation, measured by export activities, did not capture the full complexity of the concept, such as internationalisation destination, internationalisation speed, internationalisation exposure or the number of foreign markets entered. We leave these, however, to future research. Furthermore, future work should explore the potential role of firm performance in altering the relationship between networks and exporting. However, this may be better explored within a panel framework in which firm performance can be observed over time and linked to the subsequent internationalisation activities and decisions of the firm. Additionally, prolonged adverse macroeconomic conditions can also alter internationalisation decisions. Future studies should consider these factors. An additional avenue for future research can also be the distinction between family and non-family firms with a view to understanding how their networking behaviour for internationalisation purposes differs from each other.

To conclude, and reflecting on many of the previous studies of SMEs, our findings lend some prima facie support to the argument that there is a threshold of around ten employees with respect to the propensity for using formal interpersonal networks for internationalisation purposes. We argue that at around this size, firms start to become more complex and require different types of networks to gain knowledge, information and the support needed for internationalisation. This implies that firms below this threshold are not encouraged to seek advice/information or to network, and this should be a concern for policymakers. Finally, our results highlight the importance of formal networks, which in turn has important managerial implications for owner-managers seeking to expand their businesses across borders.

\section{Funding:}

This research did not receive any specific grant from funding agencies in the public, commercial or not-for-profit sectors. 


\section{References:}

Almeida, P., Dokko, G., \& Rosenkopf, L. (2003). Start-up size and the mechanisms of external learning: Increasing opportunity and decreasing ability? Research Policy, 32(2), 301-315.

Anand, V., Glick, W. H., \& Manz, C. C. (2002). Thriving on the knowledge of outsiders: Tapping organizational social capital. Academy of Management Excutive, 16(1), 87-101.

Anderson, S., Evers, N., \& Griot, C. (2013). Local and international networks in small firm internationalization: Cases from the Rhône-Alpes medical technology regional cluster. Enterpreneurship \& Regional Development, 25(910), 867-888.

Axelsson, B., \& Easton, G. (1992). Industrial networks: A new view of reality. London: Routledge.

Baldwin, J., \& Rafiquzzaman, M. (1998). The effect of technology and trade on wage differentials between non-production and production workers in Canadian manufacturing. Statistics Canada, Analytical Studies Branch Research Paper No 98.

Bennett, R. J. (2008). SME policy support in Britain since the 1990s: What have we learnt? Environment and Planning C-Government and Policy, 26(2), 375-397.

Bennett, R. J., \& Robson, P. J. A. (1999). Intensity of interaction in supply of business advice and client impact: A comparison of consultancy, business associations and government support initiatives for SMEs. British Journal of Management, 10(4), 351-369.

Bennett, R. J., \& Robson, P. J. A. (2003). Changing use of external business advice and government supports by SMEs in the 1990s. Regional Studies, 37(8), 795-811.

Bernard, A. B., \& Jensen, J. B. (1999). Exceptional exporter performance: Cause, effect or both? Journal of International Economics, 47(1), 1-25.

Birley, S. (1985). The role of networks in the entrepreneurial process. Journal of Business Venturing, 1, 107-117.

Björkman, I., \& Kock, S. (1995). Social relationships and business networks: The case of Western companies in China. International Business Review, 4(4), 519-535.

Boehe, D. (2013). Collaborate at home to win abroad: How does access to local network resources influence export behaviour? Journal of Small Business Management, 51(2), 167182.

Bonaccorsi, A. (1992). On the relationship between firm size and export intensity. Journal of International Business Studies, 23(4), 605-636.

Boter, H., \& Lundström, A. (2005). SME perspective on business support services: The role of company size, industry and location. Journal of Small Business and Enterprise Development, 12(2), 244-258.

Brüderl, J., \& Preisendörfer, P. (1998). Network support and the success of newly founded businesses. Small Business Economics, 10, 213-255.

Brunetto, Y., \& Farr-Wharton, R. (2007). The moderating role of trust in SMEs owner/managers' decision-making about collaboration. Journal of Small Business Management, 45(3), 362-387.

Cassiman, B., \& Golovko, E. (2011). Innovation and internationalization through exports. Journal of International Business Studies, 42, 56-75. 
Chandra, Y., Styles, C., \& Wilkinson, I. (2009). The recognition of first time international entrepreneurial opportunities: Evidence from firms in knowledge-based industries. International Marketing Review, 26(1), 30-61.

Chetty, S. K., \& Blankenburg-Holm, D. (2000). Internationalisation of small to medium-sized manufacturing firms: A networks approach. International Business Review, 9, 77-93.

Coleman, J. S. (1988). Social capital in the creation of human capital. The American Journal of Sociology, 94, S95-120.

Coviello, N. E. (2006). The network dynamics of international new ventures. Journal of International Business Studies, 37, 713-731.

Coviello, N. E., \& Munro, H. J. (1995). Growing the entrepreneurial firm: Networking for international market development. European Journal of Marketing, 29(7), 49-61.

Coviello, N. E., \& Munro, H. J. (1997). Network relationships and the internationalistion process of the small software firms. International Business Review, 6, 361-386.

Curran, J., Jarvis, R., Blackburn, R., \& Black, S. (1993). Networks and small firms: Constructs, methodological strategies and some findings. International Small Business Journal, 11, 13-25.

Das, M. (1994). Successful and unsuccessful exporters from developing countries: Some preliminary findings. European Journal of Marketing, 28(12), 19-33.

Das, T. K., \& Teng, B. S. (1997). Time and entrepreneurial risk behaviour. Entrepreneurship Theory \& Practice, 22(2), 69-88.

Dean, J., Holmes, S., \& Smith, S. (1997). Understanding business networks: Evidence from manufacturing and service sectors in Australia. Journal of Small Business Management, 35(1), 79-84.

Department of Business Innovation and Skills (April 2013). Small Business Survey 2012: SME Employers, A report by BMG Research.

Department for Business, Innovation and Skills. (2016). Longitudinal Small Business Survey, Year One, 2015, [data collection], UK Data Service. SN: 7973, http://doi.org/10.5255/UKDA-SN-7973-1 [Accessed 20 August 2016].

De Vries, K. (2000). Creative rebels with a cause. In: S. Birely, \& D. Muzyka (Eds.), Mastering Entrepreneurship (pp. 5-8). Harlow: Pearson.

Donckels, R., \& Lambrecht, J. (1995). Networks and small business growth: An explanatory model. Small Business Economics, 7(4), 273-289.

Dubini, P., \& Aldrich, H. (1991). Personal and extended networks are central to the entrepreneurial process. Journal of Business Venturing, 6, 306-313.

Duchesneau, D. A., \& Gartner, W. B. (1990). A profile of new venture success and failure in an emerging industry. Journal of Business Venturing, 5(5), 297-312.

Eberhard, M., \& Craig, J. (2013). The evolving role of organisational and personal networks in international market venturing. Journal of World Business, 48, 385-397.

Ellis, P. D. (2000). Social ties and foreign market entry. Journal of International Business Studies, 31(3), 443-469. 
Ellis, P. D. (2011). Social ties and international entrepreneurship: Opportunities and constraints affecting firm internationalization. Journal of International Business Studies, 42, 99-127.

Ellis, P. D., \& Pecotich, A. (2001). Social factors influencing export initiation in small and medium-sized enterprises. Journal of Marketing Research, 38(1), 673-95.

Evers, N., \& Knight, J. (2008). Role of international trade shows in small firm internationalization: A network perspective. International Marketing Review, 25(5), 544-562.

Evers, N., \& O'Gorman, C. (2011). Improvised internationalization in new ventures: The role of prior knowledge and networks. Entrepreneurship \& Regional Development, 23(7-8), 549574.

Fernández-Olmos, M., Gargallo-Castel, A., \& Giner-Bagües, E. (2016). Internationalisation and performance in Spanish family SMEs: The W-curve. Business Research Quarterly, 19, $122-136$.

Fernhaber, S. A., Gilbert, B. A., \& McDougall, P. P. (2008). International entrepreneurship and geographic location: An empirical examination of new venture internationalization. Journal of International Business Studies, 39(2), 267-290.

Fernhaber, S. A., \& Li, D. (2012). International exposure through network relationships: Implications for new venture internationalization. Journal of Business Venturing, 28(2), 316334.

Fincham, R. (1999). The consultant-client relationship: critical perspectives on the management of organizational change. Journal of Management Studies, 36(3), 335-351.

Florin, J., Lubatkin, M., \& Schulze, W. (2003). A social capital model of high-growth ventures. Academy of Management Journal, 46(3), 374-384.

Francioni, B., Vissak, T., \& Musso, F. (2017). Small Italian wine producers' internationalization: The role of network relationships in the emergence of late starters. International Business Review, 26, 12-22.

Ge, G. L., \& Wang, H. Q. (2013). The impact of network relationships on internationalization process: An empirical study of Chinese private enterprises. Asia Pacific Journal of Management, 30, 1169-1189.

Ghauri, P. N., Tasavori, M., \& Zaefarian, R. (2014) Internationalisation of service firms through corporate social entrepreneurship and networking. International Marketing Review, 31(6), 576-600.

Gino, F., Brooks, A. W., \& Schweitzer, M. E. (2012). Anxiety, advice, and the ability to discern: Feeling anxious motivates individuals to seek and use advice. Journal of Personality and Social Psychology, 102(3), 497-512.

Golovko, E., \& Valentini, G. (2011). Exploring the complementarity between innovation and export for SMEs growth. Journal of International Business Studies, 42, 362-380.

Granovetter, M. S. (1983). The strength of weak ties: a network theory revisited. Sociological Theory, 1(1), 201-233.

Graves, C., \& Shan, Y. G. (2014). An empirical analysis of the effect of internationalization on the performance of unlisted family and nonfamily firms in Australia. Family Business Review, 27(2), 142-160. 
Gujarati, D. N. (1995). Basic Econometris. McGraw-Hill International Editions, Third Edition, Singapore.

Gulati, R., \& Gargiulo, M. (1999). Where do interorganizational networks come from? American Journal of Sociology, 104(5), 1439-1438.

Haddoud, M.Y., Jones, P., \& Newbery, R. (2017). Export promotion programmes and SMEs' performance: Exporting the network promotion role. Journal of Small Business and Enterprise Development, 24(1), 68-87.

Hånell, S. M., \& Ghauri, P. N. (2016). Internationalization of smaller firms: Opportunity development through networks. Thunderbird International Business Review, 58, 465-477.

Higón, A. D., \& Driffield, N. (2010). Exporting and innovation performance: analysis of the annual Small Business Survey in the UK. International Small Business Journal, 29(1), 4-24.

Hoang, H., \& Antoncic, B. (2003). Network-based research in entrepreneurship: A critical review. Journal of Business Venturing, 18(2), 165-187.

Hohenthal, J., Johanson, J., \& Johanson, M. (2014). Networks Knowledge and businessrelationship value in the foreign market. International Business Review, 23, 4-19.

Holmlund, M., \& Kock, S. (1998). Relationships and the internationalisation of Finnish small and medium-sized companies. International Small Business Journal, 16, 46-63.

Huggins, R. (2010). Forms of network resource: Knowledge access and the role of inter-firm networks. International Journal of Management Reviews, 12(3), 335-352.

Ibarra, H. (1993). Personal networks of women and minorities in management: A conceptual framework. Academy of Management Review, 18(1), 56-87.

Inkpen, A. C., \& Tsang, E. W. K. (2005). Social capital, networks, and knowledge transfer. Academy of Management Review, 30, 146-165.

Jack, S., Rose, M., \& Johnston, L. (2009). Tracing the historical foundations of social networks in entrepreneurial research. In: ISBE Liverpool annual conference.

Jarillo, C. J. (1989). Entrepreneurship and growth: The strategic use of external resources. Journal of Business Venturing, 4(2), 133-147.

Johannisson, B. (1987). Anarchists and organizers: Entrepreneurs in a network perspective. International Studies of Management and Organization, 17(1), 49-63.

Johannisson, B., Alexanderson, O., Nowicki, K., \& Senneseth, K. (1994). Beyond anarchy and organization: Entrepreneurs in contextual networks. Entrepreneurship \& Regional Development, 6, 329-356.

Johanson, J., \& Mattsson, L. (1988). Internationalization in industrial systems-a network approach. In: P. J. Buckley, \& P. N. Ghauri (Eds.), The internationalization of the firm: A reader (pp. 303-321). London: Academic Press, 303-321.

Johanson, J., \& Vahlne, J. E. (1992). Management of foreign market entry. Scandinavian International Business Review, 1(3), 9-27.

Johnson, S., Webber, D. J., and Thomas, W. (2007). Which SMEs use external business advice? A multivariate subregional study. Environment and Planning A, 39(8), 1981-1997.

Kingsley, G., \& Malecki, E. J. (2004). Networking for competitiveness. Small Business Economics, 23, 71-84. 
Komulainen, H., Mainela, T., \& Tahtinen, J. (2006). Social networks in the initiation of a high-tech firm's internationalisation. International Journal of Entrepreneurship and Innovation Management, 6(6), 526-541.

Larson, A. (1992). Network dyads in entrepreneurial settings: A study of the governance of exchange relationships. Administrative Science Quarterly, 37(1), 76-104.

Larsson, E., Hedelin, L., \& Garling, T. (2003). Influence of expert advice on expansion goals of small businesses in rural Sweden. Journal of Small Business Management, 41(2), 205-212.

Lavie, D. (2006). The competitive advantages of interconnected firms: An extension of the resource-based view of the firm. Academy of Management Review, 31(3), 638-658.

Lechner, C., \& Dowling, M. (2003). Firm networks: External relationships as source for growth and competitiveness of entrepreneurial firms. Entrepreneurship \& Regional Development, 15, 1-26.

Leonidou, L. (2004). An analysis of the barriers hindering small business export development. Journal of Small Business Management, 42(3), 297-302.

Liesch, P. W., \& Knight, G. A. (1999). Information internalization and hurdle rates in small and medium enterprise internationalization. Journal of International Business Studies, 30(2), 383-339.

Liesch, P. W., Welch, L. S., Welch, D., McGaughey, S. L., Peterson, B., \& Lamb, P. (2002). Evolving strands of research on firm internationalization: An Australian-Nordic perspective. International Studies of Management and Organization, 32(1), 16-35.

Mackinnon, D., Chapman, K., \& Cumbers, A. (2004). Networking, trust and embeddedness amongst SMEs in the Aberdeen oil complex. Entrepreneurship \& Regional Development, 16(2), 87-106.

Manolova, T. S., Manev, I. M., \& Gyoshev, B. S. (2010). In good company: The role of personal and inter-firm networks for new-venture internationalization in a transition economy. Journal of World Business, 45, 257-265.

Masciarelli, F., Laursen, K., \& Principe, A. (2009). Trapped by over-embeddedness: The effects of regional social capital on internationalisation. Copenhagen: Copenhagen Business School Conference, pp. 1-40.

McAuley, A. (1993). The perceived usefulness of export information sources. European Journal of Marketing, 27(10), 52-64.

McDonald, I. M., \& Westphal, J. D. (2003). Getting by with the advice of their friends: CEO's advice networks and firms' strategic responses to poor performance. Administrative Quarterly, 48, 1-32.

McGrath, C. A., Vance, C. M., \& Gray, E. R. (2003). With a little help from their friends: Exploring the advice networks of software entrepreneurs. Creativity and Innovation Management, 12, 2-10.

Menon, T., \& Pfeffer, J. (2003). Valuing internal vs. external knowledge: Explaining the preference for outsiders. Management Science, 49, 497-513.

Miesenbock, K. J. (1988). Small business and exporting: A literature review. International Small Business Journal, 6(1), 42-61. 
Milanov, H., \& Fernhaber, S. A. (2014). When do domestic alliances help ventures abroad? Direct and moderating effects from a learning perspective. Journal of Business Venturing, 29(3), 377-391.

Mitchell, J. C. (1969). The concept and use of social networks. In: J. C. Mitchell (Ed.), Social networks in urban situations (pp. 1-50). Manchester, UK: Manchester University Press.

Mole, K., North, D., \& Baldock, R. (2016). Which SMEs seek external support? Business characteristics, management behaviour and external influence in a contingency approach. Environment and Planning C-Government and Policy, 0(0), 1-24.

Mort, O., \& Weerawardena, J. (2006). Networking capability and international entrepreneurship: How networks function in Australian Born Global firms. International Marketing Review, 23(5), 549-572.

Musteen, M., Francis, J., \& Datta, D. K. (2010). The influence of international networks on internationalization speed and performance: A study of Czech SMEs. Journal of World Business, 45,197-205.

Narooz, R., \& Child, J. (2016). Networking responses to different levels of institutional void: A comparison of internationalizing SMEs in Egypt and the UK. International Business Review, http://dx.doi.org/10.1016/j.ibusrev.2016.12.008

Nebus, J. (2006). Building collegial information networks: A theory of advice network generation. Academy of Management Review, 31, 615-637.

Ojala, A. (2009). Internationalization of knowledge-intensive SMEs: The role of network relationships in the entry to a psychically distant market. International Business Review, 18, 50-59.

Oparaocha, G. O. (2015). SMEs and international entrepreneurship: An institutional network perspective. International Business Review, 24(5), 861-873.

Oviatt, B. M., \& McDougal, P. P. (2005). Defining international entrepreneurship and modelling the speed of internationalisation. Entrepreneurship Theory \& Practice, 29(5), 537554.

Penrose, E. (1959). The theory of the growth of the firm. Oxford: Oxford University Press.

Peterson, R., \& Rondstadt, H. (1986). A silent strength: Entrepreneurial know-who. 16th European Small Business Seminar, Sweden, Lund-Jonkoping.

Porter, M. E. (1998). The Adam Smith address: Location, clusters, and the 'new' microeconomic of competition. Business Economics, 33(1), 7-13.

Potts, A. J. (1977). A study of the success and failure rates of small businesses and the use or non-use of accounting information. Unpublished Doctoral Thesis George Washington University.

Powell, W. W. (1990). Neither Market nor Hierarchy: Network Forms of Organization. In B. M. Staw, \& L. L. Cummings, (eds.) Research in organizational behavior, vol. 12. Greenwich, CT, JAI Press, pp. 295-336.

Prashantham, S., \& Birkinshaw, J. (2015) Choose your friends carefully: Home-country ties and new venture internationalization. Management International Review, 55, 207-234.

Rammer, C., \& Schmiele, A. (2009). Drivers and effects of internationalizing innovation by SMEs. The Icfai University Journal of Knowledge Management, 7(2), 18-61. 
Robert, M. R. D., \& Antoncic, H. B. (2006). SME internationalization research: Past, present, and future. Journal of Small Business and Enterprise Development, 13(4), 476-497.

Robson, P. J. A., \& Bennett, R. J. (2000). The use and impact of business advice by SMEs in Britain: An empirical assessment using logit and ordered logit models. Applied Economics, $32,1675-1688$.

Roper, S., \& Love, J. H. (2002). Innovation and export performance: Evidence from UK and German manufacturing plants. Research Policy, 31, 1087-1102.

Rosenbaum, G. O. (2017). Female entrepreneurial networks and foreign market entry. Journal of Small Business and Enterprise Development, 24(1), 119-135.

Saridakis, G., Mole, K., \& Hay, G. (2012). Liquidity constraints in the first year of trading and firm performance. International Small Business Journal, 31(5), 520-535.

Serra, F., Pointon, J., \& Abdou, H. (2012). Factors influencing the propensity to export: A study of UK and Portuguese textile firms. International Business Review, 21, 210-224.

Shane, S. (2003). A general theory of entrepreneurship. Cheltenham, Edward Elgar.

Sharma, D. D., \& Johanson, J. (1987). Technical consultancy in internationalisation. International Marketing Review, 4(4), 20-29.

Singh, R. P. (2000). Entrepreneurial opportunity recognition through social networks. New York, Garland.

Sparrowe, R. T., Liden, R. C., Wayne, S. J., \& Kraimer, M. L. (2001). Social networks and the performance of individuals and groups. Academy of Management Journal, 44(2), 316325.

Spence, M. (1973). Job market signalling. Quarterly Journal of Economics, 87(3), 355-374.

Stock, H. J., \& Watson, M. M. (2012). Introduction to econometrics. $3^{\text {rd }}$ ed. Harlow, UK, Pearson Education Limited.

Stoian, M. C., Rialp, J., \& Dimitratos, P. (2017). SME networks and international performance: Unveiling the significance of foreign market entry. Journal of Small Business Management, 55(1), 128-148.

Stoian, M. C., Rialp, A., Rialp, J., \& Jarvis, R. (2016). Internationalisation of central and eastern European small firms: Institutions, resources and networks. Journal of Small Business and Enterprise Development, 23(1), 105-121.

Sweeney, G. P. (1987). Innovation, entrepreneurs and regional development. New York, St Martin's Press.

Tang, Y. K. (2011). The influence of networking on the internationalization of SMEs: Evidence from internationalized Chinese firms. International Small Business Journal, 29(4), 374-398.

Turnbull, P., Ford, D., \& Cunningham, M. (1996). Interaction, relationships and network in business markets: An evolving perspective. Journal of Business and Industrial Marketing, 11(3/4), 44-62.

Uzzi, B. (1997). Social structure and competition in interfirm networks: The paradox of embeddedness. Administrative Science Quarterly, 42(1), 35-67.

Watson, J. (2007). Modelling the relationship between networking and firm performance. Journal of Business Venturing, 22, 852-874. 
Welch, L. S., \& Wiedersheim-Paul, F. (1980). Initial exports: A marketing failure? Journal of Management Studies, 17, 334-344.

Westhead, P., Wright, M., \& Ucbasaran, D. (2004). Internationalization of private firms: Environmental turbulence and organizational strategies and resources. Entrepreneurship \& Regional Development, 16, 501-522.

Westphal, J. D., Boivie, S., \& Chng, D. H. M. (2006). The strategic impetus of social network ties: Reconstituting broken CEO friendship ties. Strategic Management Journal, 27(5), 425445.

Williamson, O. (1985) The economic institutions of capitalism. New York, The Free Press.

Yiu, D. W., Lau, C., \& Bruton, G. D. (2007). International venturing by emerging economy firms: The effects of firm capabilities, home country networks, and corporate entrepreneurship. Journal of International Business Studies, 38(4), 519-540.

Yu, J., Gilbert, B. A., \& Oviatt, B. M. (2011). Effects of alliances, time, and network cohesion on the initiation of foreign sales by new ventures. Strategic Management Journal, 32(4), 424-446.

Zaefarian, R., Eng, T. Y., \& Tasavori, M. (2016). An exploratory study of international opportunity identification among family firms. International Business Review, 25, 333-345.

Zahra, S. A. (2005). A theory of international new ventures: A decade of research. Journal of International Business Studies, 36(1), 20-28.

Zain, M., \& Ng, S. I. (2006). The impact of network relationships on SMEs' internationalization process. Thunderbird International Business Review, 48(2), 183-205.

Zhang, X., Ma, X., \& Wang, Y. (2012). Entrepreneurial orientation, social capital, and the internationalization of SMEs: Evidence from China. Thunderbird International Business Review, 54(2), 195-210.

Zhang, X., Ma, X., Wang, Y., Li, X., \& Huo, D. (2016). What drives the internationalization of Chinese SMEs? The joint effects of international entrepreneurship characteristics, network ties, and firm ownership. International Business Review, 25, 522-534.

Zhou, L., Wu, W. P., \& Luo, X. (2007). Internationalization and the performance of bornglobal SMEs: The mediating role of social networks. Journal of International Business Studies, 38(4), 673-690. 


\section{Appendix}

Table A1: Descriptive statistics of study and controlled variables (means and proportions)

\begin{tabular}{llll}
\hline Variable & Obs. & Mean & Std. Dev \\
\hline Export & 15287 & 0.216 & 0.411 \\
Size & 15287 & 1.979 & 1.645 \\
Age & 15287 & 3.201 & 1.076 \\
Legal & 15287 & 2.035 & 0.682 \\
Sites & 15287 & 1.389 & 0.921 \\
Region & 15287 & 1.234 & 0.663 \\
Sector & 15287 & 7.013 & 3.784 \\
Competition & 15287 & 0.500 & 0.500 \\
External advice/information & 15287 & 0.361 & 0.48 \\
Local networks & 5523 & 0.855 & 0.351 \\
Formal networks & 5523 & 0.452 & 0.479 \\
Informal networks & 5523 & 0.152 & 0.360 \\
Both networks & 5523 & 0.134 & 0.341 \\
Other networks & 5523 & 0.574 & 0.494 \\
No networks & 5523 & 0.144 & 0.351 \\
Network location & 15287 & 0.413 & 0.588 \\
Network source & 15287 & 1.465 & 2.285 \\
\hline
\end{tabular}

